\title{
TransELTE 2021 - OFFI Akadémia XXIII. Fordítástudományi Konferencia
}

(Elsö nap, online konferencia, 2021. március 25-26).

Laszlóczki László

E-mail:laszloczki.laszlo@gmail.com

„Távolléti oktatás a forditó- és tolmácsképzésben-Oktatásmódszertani tapasztalatok a Covid-19 idején" volt a címe az ELTE Fordító- és Tolmácsképző Tanszék és az Országos Fordító és Fordításhitelesítő Iroda 23 éve tartó közös konferenciasorozatában az első napnak. Ugyanezzel a címmel a konferenciát március 24-én délután megelőzte egy könyvbemutató, melyen a Fordító- és Tolmácsképző Tanszék oktatói mutatták be új tanulmánykötetüket a távolléti oktatásról. A konferencia első napján az ország különböző egyetemein és a határon túl folyó fordító- és tolmácsképzést képviselő oktatók osztották meg tapasztalataikat arról, hogy milyen tanulságok vonhatók le a pandémia alatt használt oktatási módszerekről.

Az online rendezvény első részét Horváth Ildikó, az ELTE BTK nemzetközi dékánhelyettese, az ELTE FTT tanszékvezetője, az ELTE Nyelvi Közvetítés Intézete igazgatója nyitotta meg. A bevezetőt követő előadásában kifejtette, hogy mi a lényeges különbség a távoktatás és a távolléti oktatás között. Az előbbi nem újdonság, hiszen az ELTE FTT több éve folytat távoktatást, de a távolléti oktatás sok szempontból más. A távoktatásban a tanárok és hallgatók közös platformon dolgozhatnak, ahol minden visszakereshető és rugalmas az időbeosztás. A távolléti oktatásban nincs ilyen közös platform, és az időbeosztás sem rugalmas. A távoktatást a tanszék két évig készítette elő, a távolléti oktatásban erre az előkészítő munkára nem volt lehetőség. A távoktatásban felnőttek vesznek részt, akik erre készültek, a távolléti oktatásban egyetemisták vesznek részt, akik erre nem voltak előkészítve, és a motivációjuk is más, mint a távoktatásban részt vevő felnőtteknek. Mindazonáltal a távoktatásban szerzett tapasztalatok segítették az ELTE FTT oktatóit abban, hogy távolléti oktatásra való átállás viszonylag zökkenőmentesen történjen.

A Budapesti Müszaki és Gazdaságtudományi Egyetem Idegen Nyelvi Központjának két oktatója, Szabó Csilla és Besznyák Rita The bright side of life: Pozitív oktatói és hallgatói tapasztalatok a BME TFK online tolmácsképzéséről címü

Hivatkozás: Laszlóczki L. 2021. TransELTE 2021 - OFFI Akadémia. XXIII. Fordítástudományi Konferencia (Első nap, online konferencia, 2021. március 25-26). Fordítástudomány 23. évf. 1. szám. 112-116. DOI: https://doi.org/10.35924/fordtud.23.1.9 
elöadásában arról számoltak be, hogy mit köszönhetünk az online oktatásnak. Egy friss nemzetközi felmérés eredményei mellett megmérték, hogy a magyar felsőoktatás hogyan viszonyult a digitális átálláshoz. Mindkét esetben az extra munkaterhelést emelték ki, továbbá az, hogy a felmérésben érintettek túlnyomó része tanult abból, ahogy mások megoldottak egy-egy helyzetet a jelen körülmények között. Megdöbbentő adat, hogy a magyar felsőoktatás nagyjából négyszeres terhelés alatt müködött (és müködik), aminek okai között például az eszközproblémákat lehet megemlíteni. Az előadás a járvány pozitív hozadékaként emelte ki a technológia intenzívebb bevonását, az interaktív oktatást (hallgatók bevonása a frontális módszer helyett) és többek közt a kreatívabb értékelést (audiovizuális megoldások, videó, podcastek stb.). Ezeket mindenképpen érdemes megtartani a járvány után is. Példaként kiemelték, hogy a tolmácsok oktatása során néhány esetben szinte hatékonyabb volt a képzés, mint a jelenléti óra keretében (pl. breakout room-ok létrehozása). Ezzel összefüggésben érdemes egy hallgatói véleményt is elolvasni: „Az otthon felvett tolmácsolásra is részletes és személyre szabott visszajelzést kaptunk."

Suba Réka, a Sapientia Erdélyi Magyar Tudományegyetem Marosvásárhelyi Kar Alkalmazott Nyelvészeti Tanszékének oktatója Képességek, készségek a távolléti oktatásban címü előadása során a romániai tapasztalatokat osztotta meg a hallgatósággal. Az e-learning (elektronikus tanulás) és a blended learning (vegyes tanulás) fogalmain túl tisztázta a sokak számára újdonságként ható m-learning fogalmát is. M-learning alatt a mobil telekommunikációs eszközök segítségével megvalósuló oktatási formát érti, ahol létrejön az e-learning és a mobiltechnológia fúziója. Kiemelte, hogy ezek hatékony müködésének feltétele a digitális eszközök és a kulcskompetenciák megléte, rendszergazdák, adminisztrátorok, tananyagfejlesztők és oktatók összehangolt munkája. Hogy erről pontosabb képek kapjanak, 2021 februárjában a Marosvásárhelyi Kar Alkalmazott Nyelvészeti Tanszék készített egy online kérdöíves felmérést a fordító és tolmács alapszak hallgatói körében, amely a Google Tanterem hatékonyságára, a hallgatóknak az online oktatással, a szinkron és aszinkron módszerekkel kapcsolatos tapasztalataira és véleményére, a hallgatók virtuális osztálytermi interakcióira volt kíváncsi. Összegzésként a következö tapasztalatokat vonták le: a hallgatóknak az oktatókkal és a diáktársakkal való személyes interakciók hiánya okozta a legnagyobb kihívást, a társasági élet hiánya mellett a koncentrációt és a motivációt is rendkívül nehéz volt fenntartani az online tanulási környezetben. A hallgatók úgy nyilatkoztak, hogy leginkább a videokonferencia-jellegű tanórákat részesítik előnyben, föleg, ha azok elektronikus tananyagokkal vannak kiegészítve.

Bakti Mária, a Szegedi Tudományegyetem Juhász Gyula Pedagógusképző Kar oktatója A konszekutivv tolmácsolás távolléti oktatása az SZTE tolmács mesterképzésben. Oktatói és hallgatói nézőpontok címü elöadásában a távolléti oktatás szegedi megvalósulásáról beszélt. Egy feleletválasztós és rövid válaszokat igénylő (online) kérdöív eredményeit felhasználva arra a következtetésre jutottak, hogy a távolléti oktatásnak több pozitívuma is van. A hallgatók szerint az oktatás interak- 
tívan zajlott, hasznosnak tartották az új platformok kipróbálását, miközben nyugodt, kényelmes körülmények között kevésbé stresszesen tudták elsajátítani a tananyagot. A negatívumok között többek közt az esetenként előforduló rossz hangminőséget, a személytelenséget és az ezekből adódó kínos csendeket és a passzivitást említették meg. A kérdőívet két oktató is kitöltötte: az egyik abszolút pozitív, a másik határozottan negatív véleménnyel volt az online oktatásról. A videótolmácsolás életszerü gyakorlását mindketten előnyként fogalmazták meg.

A délutáni program első blokkját Klaudy Kinga, az ELTE FTT Fordítástudományi Doktori Programjának vezetője nyitotta meg. A Sketch Engine használata a vizsgadolgozatok korpuszának elemzésére című előadása a Károli Gáspár Református Egyetem konferenciáján 2021. január 28-án tartott előadásának folytatása volt. Klaudy Kinga kihasználva azt az elönyt, hogy a hallgatók vizsgadolgozatait a Canvas közös platformnak köszönhetően digitalizálva kapta meg, két automatikusan elemezhető korpuszt épített a hallgatók dolgozataiból, melyeket a Sketch Engine segítségével elemzett. A Sketch Engine különböző funkcióival számszerü adatokat tud szolgáltatni a betöltött szövegekröl: automatikusan kikeresi a szövegek kulcsszavait, bármelyik szónak megadja a konkordanciáját, azaz kikeresi a baloldali és a jobboldali környezetet, megkeresi a szinonimákat stb. A „Saját vélemény" korpuszból az előadó azt kívánta megtudni, hogy a hallgatók mennyire találták hasznosnak a fordítástudományi előadásokat, a „Választott olvasmány” korpuszban azt vizsgálta, milyen témák érdeklik a hallgatókat. A „Saját vélemény” korpusz vizsgálatának eredményeiről már beszámolt a Károli Gáspár Református Egyetemen tartott előadásában, amelyről a Forditástudománynak ebben a számában olvashatnak összefoglalást. A TransELTE konferencián tartott a elöadásában a „Választott olvasmány” eredményeire helyezte a hangsúlyt. Megállapította, hogy a hallgatók sokkal érdekesebb és változatosabb témákat választottak, mint amikor elöre megkapott olvasmányjegyzékből kellett választaniuk. A „Választott olvasmány" korpuszból kapott adatok alapján a leggyakrabban a gépi fordítás és utószerkesztés, valamint az audiovizuális fordítás témájából választottak olvasnivalót a hallgatók szabadon választott olvasmányként.

Sereg Judit, Az ELTE FTT oktatója Audiovizuális forditás oktatása online formában címü előadásában az elmúlt három szemeszter tapasztalatait gyüjtötte össze. Hasonlóan a konferencia többi előadásához, ő is az új felületek megismerésének pozitív hozadékát hangsúlyozta, továbbá kiemelte a később is felhasználható videók fontosságát. Kifejtette, hogy a rendkívüli helyzet jó alkalmat szolgáltatott az önállóság fejlesztésére és valós élményként szolgált a fordító elszigetelt munkájáról. A negatív tapasztalatok közé a személyes kapcsolatok hiányát, a vendégelöadók elvesztését, a stúdiólátogatás elmaradását sorolta.

A délutáni ülés következő előadója Stötzer Andrea, az SZTE ÁOK Orvosi Szaknyelvi Kommunikációs és Fordítóképző Csoport oktatója volt. Előadásának címe: Távolléti oktatás - közelről. A 2020. márciusi rendkívüli (rektori és tavaszi) szünet Szegeden is nagy kihívás elé állította az oktatókat. Stötzer Andrea kifejtette, hogy alapvető különbség van online és távolléti oktatás között. Előbbi időhöz 
nem kötött, nem valós idejü, visszanézhető és ismételhető, továbbá a tudás ellenörzése sem hagyományos módon megy végbe. Az újonnan bevezetett távolléti oktatás nehézségét az adja, hogy időben ugyanúgy kötött, mint a jelenléti oktatás, így a valós idejüsége miatt korlátozott lehetőségek vannak az ismétlésre (pl. az adatvédelmi szabályok miatt). Ebben az esetben a tudás ellenőrzése még hagyományos módszereken alapszik. A bevált gyakorlatoknál a konferencia hallgatói megtudhatták, hogy a Zoom breakout room funkciója nagyon hasznos lehet a konszekutív tolmácsolás órai gyakorlása során, szókincsbővítéshez pedig a Quizlet nyújtott segítséget. Az előadó a távolléti oktatás pozitív hozadéka között a videokonferencia elönyeit jelölte meg és hozzátette, hogy a tolmácshallgatóknak több otthon elkészítendő tolmácsolási feladatot fog adni. A fordítás oktatásával kapcsolatban a képernyőmegosztás fontosságát emelte ki: a keresési technikák, a böngészés jó gyakorlatai és a hasznos oldalak azonnali ismertetése nagymértékben hozzájárul a hallgatók fejlödéséhez. A hallgatói visszajelzésekböl kiderült, hogy ha lehetne, majdnem mindenki visszatérne a jelenléti oktatáshoz, hiszen technikai nehézségek egyaránt adódtak hallgatói és oktatói oldalon. Az oktatók úgy vélekedtek, hogy a felkészülés sokkal több időt és energiát vett igénybe, emiatt az elmúlt időszak rendkívül fárasztó és egészségkárosító volt mindenki számára.

Az alap-, mester- és posztgraduális képzésen résztvevő hallgatók mellett kimondottan a PhD-hallgatókról szólt Seidl-Péch Olívia, a Budapesti Müszaki és Gazdaságtudományi Egyetem Gazdaságtudományi Kar Idegen Nyelvi Központ oktatójának Hogyan kisérjünk az online térben? Témavezetői feladatok a távolléti $P h D$ védésig címü előadása. Az előadó fontos alapvetésként definiálta, hogy elsősorban a doktorandusz hallgató a felelős a saját fejlődéséért, hiszen szakértőnek számít a saját kutatási területén. A témavezető elsődleges feladata a doktorandusz felelősségének tudatosítása és elkötelezettségének motiválása. A doktoranduszok elakadásának legfőbb okai közt a motiváció hiányát, felkészületlenségét, az időhiányt, a megfelelő téma hiányát és az elegendő szakirodalom hiányát jelölte meg. A hatékony $\mathrm{PhD}$ kísérés alapelvei közé Seidl-Péch Olívia a következőket sorolja: megoldásközpontú kísérési folyamat, a doktorandusz egyéni felelősségének tudatosítása, magas feladatorientáltság, tiszta és határozott keretek, szakmai és tudományos együtt gondolkodás. Ebben a témavezető úgy tud a hallgatónak segíteni, ha pontosan behatárolja a témát, segít a kutatási eszköz kiválasztásában, kialakítja a megfelelö ütemezést, félévenként beszámolót kér a hallgatójától, továbbá átsegíti a doktoranduszt elakadása során. Ezek a faktorok vezethetnek a disszertáció megírásához és a sikeres védéséhez. Az online térben védett disszertáció a személyes kontaktusok hiányában rendkívül nehéz: a hallgató szakmailag elszigeteli magát, máshogyan értékeli a kritikát, nehezen különbözteti meg a hibákat és a kritikákat, emellett a bírálatokat sem tudja olyan hatékonyan feldolgozni, mint a jelenléti oktatás idején. Ezeket elkerülendő, Seidl-Péch Olívia olyan javaslattal élt, hogy a védés anyagát küldjék meg a képzés összes érintett oktatójának és hallgatójának, továbbá tegyék lehetővé, hogy a hallgatók és oktatók és hozzászólhassa- 
nak a dolgozathoz. A témavezetők konzultációk keretében segítsenek a hallgatónak az elöopponensi észrevételek értelmezésében.

A délutáni szekció második blokkját a Károli Gáspár Református Egyetem oktatói, Adorján Mária, Dróth Júlia, Kovács Tímea és M. Pintér Tibor Forditási és szaknyelvi gyakorlatok távolsági oktatásban címü előadása nyitotta meg. Dróth Júlia a bevezetőjében elmondta, hogy a 2020 tavaszi átmeneti időszak során kellett kialakítani a távoktatási képzési formáit (az online oktatás technikai feltételeit és az oktatás módszereit), mert ezzel korábban nem rendelkezett a KRE. Ebben az időszakban nagy szerepe volt a tanári kompetenciáknak, többek közt a találékonyságnak, az alkalmazkodásnak és a szeretetteljes figyelemnek is. Hangsúlyozta, hogy az egyéni tanulás támogatását és nyomon követését a jövőben érdemes fokozottan alkalmazni. Kiemelte, hogy az idő múlásával változnak a fordítói kompetenciák és a normák, amely többek között olyan kérdéseket vet fel például, hogy elfogadja-e a diák, amit a tanár hibának vesz? Ismeri-e a tanár a fiatal generáció nézeteit a CNY-i szöveg minőségéről? Tudatában van-e a tanár a hallgatók nyelvhasználati szokásainak? Ezek miatt precízebb írásbeli értékelésre van szükség. Érdemes figyelembe venni azt a tényt is, hogy a hallgatók sokkal aktívabbak, nyitottabbak és felszabadultabbak voltak az online térben. Dróth Júlia szót ejtett még a gépi fordítás kérdéséről is. Megállapította, hogy a Google Translate-tel fordított szövegek sokszor jobb minőségü szöveget adnak, mint a hallgatók megoldásai, ezért nehéz fordítási feladatot adni házi feladatnak. Összegzésként hat fajta tanulási módot határozott meg, ezek az elsajátítás, kutatás, megbeszélés, gyakorlás, együttműködés és a produktum létrehozása.

Petz András, az Anglofon Studio alapítója Integrált e-learning platform használata gazdasági és jogi terminológia oktatásában címmel tartott előadása elsősorban a jogi szaknyelv iránt érdeklődőknek és jogászoknak volt érdekes, de természetesen a digitális tanulási platformok használatának előnyei mindenki számára értékes és új információként szolgáltak.

Sohár Anikó, a Pázmány Péter Katolikus Egyetem oktatója Felhívás keringöre. Csoportmunka távolléti oktatásban címü előadása során mutatta be az Yves Gambier és Luc van Doorslaer által szerkesztett és a John Benjamins Publishing Company által kiadott Handbook of Translation Studies (HTS) magyar nyelvü online verzióját, melyben a PPKE fordítóképzésben résztvevő hallgatói kezdték el magyarra fordítani a szócikkeket. Javaslatot tett arra, hogy ebben a munkában vegyen rész az összes magyar fordítóképző egyetem, hogy létre lehessen hozni a HTS magyar változatát. A távolléti oktatási forma alkalmas lenne ennek a munkának az elvégzésére, egyetemközi fordító és lektoráló csoportok kialakításával. 